\title{
Hepatotoxicity and effectiveness of a Nevirapine- based antiretroviral therapy in HIV-infected patients with or without viral hepatitis B or C infection in Cameroon
}

Jules B Tchatchueng Mbougua ${ }^{1,2}$, Christian Laurent ${ }^{1 *}$, Charles Kouanfack ${ }^{3}$, Anke Bourgeois ${ }^{1,4}$, Laura Ciaffi ${ }^{5}$, Alexandra Calmy ${ }^{5}$, Henri Gwet ${ }^{2}$, Sinata Koulla-Shiro ${ }^{3}$, Jacques Ducos ${ }^{6}$, Eitel Mpoudi-Ngolé ${ }^{7}$, Nicolas Molinari ${ }^{8,9}$, Eric Delaporte ${ }^{1,4}$

\begin{abstract}
Background: Coinfection with hepatitis B virus (HBV) or hepatitis C virus (HCV) in HIV-infected patients receiving a commonly used nevirapine-based antiretroviral therapy is a major concern for African clinicians owing to its high prevalence, the infrequent testing and treatment of viral hepatitis, and the impact of liver disease on the tolerability and effectiveness of anti-HIV treatment. We compared the hepatotoxicity and the immunological, virological and clinical effectiveness of a nevirapine-based antiretroviral therapy between patients infected with HIV only and patients coinfected with hepatitis B or C virus in Cameroon.

Methods: A retrospective cohort study was conducted among HIV-1-infected patients. Plasma HBV DNA and HCV RNA were tested in positive or indeterminate samples for HBsAg or HCV antibodies, respectively. All patients received nevirapine and lamivudine plus stavudine or zidovudine.

Results: Of 169 HIV-1-infected patients with a median baseline CD4 count of 135 cells/mm (interquartile range [IQR] 67-218), $21 \%$ were coinfected with HBV or HCV. In coinfected patients, the median viral load was $2.47 \times 10^{7}$ $\mathrm{IU} / \mathrm{mL}$ for HBV (IQR 3680-1.59 $\left.\times 10^{8}\right)$ and $928000 \mathrm{IU} / \mathrm{mL}$ for HCV (IQR $\left.178400-2.06 \times 10^{6}\right)$. Multivariate analyses showed that the risk of hepatotoxicity was 2 -fold higher in coinfected patients $(p<0.01)$. The response to antiretroviral therapy was however comparable between monoinfected and coinfected patients in terms of CD4 cell count increase $(p=0.8)$, HIV-1 viral load below 400 copies $/ \mathrm{mL}(p=0.9)$, death $(p=0.3)$ and death or new AIDS-defining event $(p=0.1)$. Nevirapine was replaced by a protease inhibitor in 4 patients owing to hepatotoxicity.
\end{abstract}

Conclusion: This study suggests that the nevirapine-based antiretroviral therapy could be used safely as first-line treatment in patients with low CD4 cell count in Africa despite frequent coinfections with HBV or HCV and infrequent testing of these infections. Although testing for HBV and HCV should be systematically performed before initiating antiretroviral therapy, transaminases elevations at baseline or during treatment should be a decisive argument for testing when hepatitis status is unknown.

\footnotetext{
* Correspondence: Christian.Laurent@mpl.ird.fr

'Institut de Recherche pour le Développement, University Montpellier 1, UMR 145, Montpellier, France
} 


\section{Background}

Coinfection with hepatitis B virus (HBV) or hepatitis $\mathrm{C}$ virus (HCV) in HIV-infected patients receiving a nevirapine-based antiretroviral therapy is a major concern for African clinicians owing to its high prevalence, the infrequent testing and treatment of viral hepatitis, and the impact of liver disease on the tolerability and effectiveness of anti-HIV treatment [1]. While HIV-related morbidity and mortality are decreasing thanks to the scaling-up of antiretroviral therapy, the impact of liver disease is likely to increase in Africa. In addition, initiation of antiretroviral therapy has been suggested in all patients coinfected with HIV and hepatitis B or C virus irrespective of the CD4 cell count.

Nevirapine, the non nucleosidic reverse transcriptase inhibitor (NNRTI) most often used in first-line treatment in combination with two nucleosidic reverse transcriptase inhibitors, is associated with early hypersensitivity reactions (generally in the first 12 weeks after treatment initiation) which can cause fulminant hepatitis leading to hepatic failure and death, and with later onset of direct drug-related hepatotoxicity leading to liver enzymes elevations [2]. The risk of hepatotoxicity is increased in patients coinfected with HBV or HCV [3-5]. The World Health Organization (WHO) therefore recommends to use nevirapine with caution and regular monitoring in patients who have baseline grade 1, 2 or 3 elevations of liver enzymes and positive or unknown HBV or HCV testing [6]. In addition, nevirapine is not recommended in patients with a grade 4 elevation of liver enzymes.

The impact of HBV or HCV coinfection on the effectiveness of a nevirapine-based antiretroviral therapy remains unclear owing to the lack of specific studies especially in the African context. A recent South African study in HBV-coinfected patients receiving the less hepatotoxic efavirenz (the second NNRTI used in firstline treatment) found similar response to antiretroviral therapy between monoinfected and coinfected patients despite higher hepatotoxicity in the latter [7]. Regardless of antiretroviral regimens (often not reported), studies on HBV or HCV coinfection in Western and Asian countries provided conflicting results with respect to CD4 cell increase, HIV suppression, AIDS progression and mortality [8-21].

We therefore compared the hepatotoxicity and the immunological, virological and clinical effectiveness of a nevirapine-based antiretroviral therapy between patients infected with HIV only and patients coinfected with HIV and hepatitis B or C virus in Cameroon [22].

\section{Methods}

\section{Study design}

A retrospective cohort study was conducted in two major hospitals (the Military Hospital and the Central Hospital) in Yaoundé, the capital of Cameroon, among HIV-1-infected patients enrolled from 2001 to 2003 in two clinical research projects designed to assess antiretroviral treatments [23-25]. The National Ethics Committee of Cameroon approved the study protocols, and the patients gave their written informed consent. The eligibility criteria, follow-up methods, medical and social staff, and coordinators were similar in the two projects. Briefly, patients over 18 years were eligible if they had confirmed HIV-1 infection, AIDS or a CD4 count below 350 cells $/ \mathrm{mm}^{3}$, a Karnofsky score over $50 \%$, and no contraindications to antiretroviral treatment, including serum liver enzyme levels less than five times the upper limit of normal (ULN) in the first project or less than three times the ULN in the second project. All patients received nevirapine and lamivudine plus stavudine or zidovudine. Tenofovir was not available. Efavirenz was temporarily substituted for nevirapine in case of concomitant tuberculosis therapy. Care (visits and laboratory exams) and drugs (antiretrovirals, and preventive and curative treatments for opportunistic infections) were provided free of charge.

\section{Clinical and laboratory procedures}

Hepatitis B and C markers were assessed on baseline blood samples frozen at $-80^{\circ} \mathrm{C}$. Enzyme immunoassays (EIA) were used to detect hepatitis B surface antigens (HBsAg; Monolisa Ag HBs Plus, Bio-rad, Marnes la coquette, France) and antibodies to hepatitis $C$ virus (anti-HCV; Ortho HCV EIA 3.0, Ortho-clinical Diagnostics, Riratan, NJ, USA). Plasma HBV DNA and HCV RNA were tested in positive or indeterminate samples for HBsAg or anti-HCV, respectively, using the Cobas Ampliprep/Cobas TaqMan quantitative assay (Roche Diagnostics $\mathrm{GmbH}$, Mannheim, Germany; quantification range of 12 to $2.2 \times 10^{8} \mathrm{IU} / \mathrm{mL}$ for $\mathrm{HBV}$ and 15 to $6.9 \times$ $10^{7} \mathrm{IU} / \mathrm{mL}$ for $\mathrm{HCV}$ ).

The CD4 cell counts were measured with a FACSCount device (Becton Dickinson, Mountain View, California, USA) at baseline and then every 6 months. The HIV-1 RNA load was determined using the Roche Amplicor HIV-1 Monitor assay (Roche Molecular Systems, Branchburg, New Jersey, USA) or the Bayer bDNA HIV-1 Quantiplex assay (Bayer Diagnostics, Emeryville, California, USA) at baseline, months 3 and 6 , and then every 6 months. Serum liver enzymes (alanine aminotransferase [ALT] and aspartate aminotransferase [AST]) levels were assayed at baseline, weeks 2, 4 
and 6, and then months 2, 3, 6, 9, 12, 18 and 24. Hepatotoxicity was graded with the French National Agency for Research on AIDS and Viral Hepatitis (ANRS) toxicity scale in which an ALT or AST level of 1.25-2.5 times the ULN defines grade $1,>2.5-5$ times the ULN defines grade $2,>5-10$ times the ULN defines grade 3 and $>10$ times the ULN defines grade $4 \mathrm{http}: / / \mathrm{www}$. anrs.fr/content/download/2242/12805/file/ANRS-GradeEI-V1-En-2008.pdf. At each time point, hepatotoxicity grade was defined on the basis of the higher value of either ALT or AST. The HIV disease stage was determined according to the 1993 Centers for Disease Control and Prevention (CDC) classification.

\section{Statistical analysis}

Patients were classified as coinfected if they had positive HBV DNA or HCV RNA. The analyses were based on an intention-to-treat approach. Data were censored at the time of each patient's month 24 visit or, if follow-up was shorter, at the time of the last visit or death. The $\chi^{2}$ test and, when sample sizes were too small, Fisher's exact test were used to compare the distribution of categorical variables between the infection groups (HBV or $\mathrm{HCV}$-coinfected patients versus HIV-monoinfected patients). For continuous variables, comparisons were based on the non parametric Mann-Whitney two-sample test.

Hepatotoxicity was first assessed by using two end points: 1) occurrence of at least one episode of grade 2 or higher hepatotoxicity, and 2) occurrence of at least one episode of grade 3 or 4 hepatotoxicity. KaplanMeier curves were plotted and differences between monoinfected and coinfected patients were checked for significance by the log-rank test. Cox proportional hazard models were used to compare hepatotoxicity between groups adjusted on baseline covariates. The proportional hazards assumption was evaluated by both graphic and statistical (based on Schoenfeld residuals) methods. A multivariate Poisson regression was then used to compare between groups the highest grade of hepatotoxicity reached by each patient during follow-up. The evolution of the CD4 cell count during follow-up was estimated using a mixed-effect linear regression model. Taking into account the biphasic evolution of the CD4 cell count during antiretroviral therapy [26], we allowed the slope to change after 6 months and included a quadratic effect in the second phase. In order to compare the CD4 cell counts evolution in monoinfected and coinfected patients, terms of interaction between infection status and each phase's slope or quadratic effect were tested. The CD4 cell counts were square root-transformed to approximate a normal distribution. The time to reach a viral load below 400 copies/ $\mathrm{mL}$, death, and death or new AIDS-defining event from treatment initiation were compared between groups by using multivariate Cox models.

Multivariate analyses were adjusted on the following baseline covariates: gender (women versus men), age ( $\geq$ 42 versus $<42$ years), time since diagnosis of HIV infection ( $<24$ versus $\geq 24$ months), body mass index $(\geq 21$ versus $\left.<21 \mathrm{~kg} / \mathrm{m}^{2}\right)$, Karnofsky score $(<100 \%$ versus $100 \%$ ), CDC clinical stage, CD4 cell count ( $\geq 100$ versus $<100$ cells $\left./ \mathrm{mm}^{3}\right)$, HIV -1 viral load $(<5.0$ versus $\geq 5.0$ $\log _{10}$ copies $/ \mathrm{mL}$ ), hemoglobin level $(\geq 10$ versus $<10 \mathrm{~g} /$ $\mathrm{dL})$, total lymphocytes count $(\geq 1700$ versus $<1700$ cells $/ \mathrm{mm}^{3}$ ), liver enzymes levels $(\geq 1.25$ versus $<1.25 \times$ ULN), antiretroviral therapy and cotrimoxazole prophylaxis. Independent covariates associated with outcomes with a conservative $p$ value of $<0.25$ in univariate analysis were subsequently tested in multivariate analysis. A backward elimination procedure was used to determine the final model containing only the infection group, together with significant covariates and potential confounders. The incidence rates of hepatotoxicity, deaths, and deaths or new AIDS-defining events were expressed as the number of patients with at least one episode of the given event per 100 person-years of follow-up. For the incidence rates as for the survival analyses, data were censored at the time of the first episode of the given event. All analyses were performed using STATA 10.01 software (STATA Corporation, college Station, TX, USA).

\section{Results}

Patients

Of 169 HIV-1-infected patients enrolled between January 2001 and April 2003, 35 (21\%) were coinfected with HBV $(\mathrm{n}=14)$ or $\mathrm{HCV}(\mathrm{n}=21)$. The baseline patient's characteristics are shown in table 1 . Two thirds of patients were women. Most patients were at an advanced HIV clinical stage (42\% were at the CDC stage B and $44 \%$ were at stage C). The median CD4 count was 135 cells $/ \mathrm{mm}^{3}$ (interquartile range [IQR] 67-218). Fifteen women (13\%; 12 monoinfected with HIV and 3 coinfected with HBV or HCV) had a CD4 count above 250 cells $/ \mathrm{mm}^{3}$. No man had a CD4 count above 400 cells $/ \mathrm{mm}^{3}$. Most characteristics were similar between HIV-monoinfected patients and those coinfected with an hepatitis virus. However, coinfected patients were older $(p<0.001)$, and had higher liver enzyme levels $(p<0.001)$. The median viral load was 2.47 $\times 10^{7} \mathrm{IU} / \mathrm{mL}$ for HBV $\left(\mathrm{IQR} 3680-1.59 \times 10^{8}\right.$; range 270 $>2.2 \times 10^{8}$ ) and $928000 \mathrm{IU} / \mathrm{mL}$ for HCV (IQR 178400 $2.06 \times 10^{6}$; range $640-5.5 \times 10^{6}$ ) in patients coinfected with the respective virus. The median time of follow-up was 23.9 months (IQR 17.2-24.0) in monoinfected patients and 24.0 months (IQR 20.0-24.0) in coinfected patients. Half the patients received zidovudine, lamivudine and nevirapine at baseline, and the other half received 
Table 1 Baseline characteristics of patients by infection group

\begin{tabular}{|c|c|c|c|c|c|}
\hline \multirow[b]{2}{*}{ Women (no.) } & \multicolumn{2}{|c|}{ HIV monoinfected patients $(n=134)$} & \multicolumn{2}{|c|}{ HBV or HCV coinfected patients $(n=35)$} & \multirow{2}{*}{$\frac{p}{0.6}$} \\
\hline & 91 & $(68 \%)$ & 22 & $(63 \%)$ & \\
\hline \multicolumn{6}{|l|}{ Age (years) } \\
\hline Median (IQR) & 34.5 & $(28.4-39.7)$ & 41.6 & $(33.7-48.8)$ & $<0.001$ \\
\hline$<42$ (no.) & 113 & $(84 \%)$ & 19 & $(54 \%)$ & $<0.001$ \\
\hline \multicolumn{6}{|c|}{ Time since diagnosis of HIV seropositivity (months) } \\
\hline Median (IQR) & 29.4 & $(13.5-53.4)$ & 22.1 & $(8.3-43.6)$ & 0.2 \\
\hline$<24$ (no.) & 56 & $(42 \%)$ & 18 & $(51 \%)$ & 0.3 \\
\hline Body weight (Kg) [median (IQR)] & 65 & $(55-70)$ & 63 & $(54-70)$ & 0.7 \\
\hline \multicolumn{6}{|l|}{ Body mass index $(\mathrm{Kg} / \mathrm{m} 2)^{*}$} \\
\hline median (IQR) & 23.2 & $(21.6-24.7)$ & 22.2 & $(20.6-25.6)$ & 0.2 \\
\hline$\geq 21$ (no.) & 108 & $(82 \%)$ & 25 & $(74 \%)$ & 0.3 \\
\hline Karnofsky score >90\% (no.) & 72 & $(54 \%)$ & 15 & $(43 \%)$ & 0.3 \\
\hline CDC clinical stage (no.) & & & & & 0.7 \\
\hline A & 19 & $(14 \%)$ & 4 & $(11 \%)$ & \\
\hline B & 58 & $(43 \%)$ & 13 & $(37 \%)$ & \\
\hline C & 57 & $(43 \%)$ & 18 & $(51 \%)$ & \\
\hline \multicolumn{6}{|l|}{ CD4 cell count (/mm3) } \\
\hline Median (IQR) & 138 & $(67-222)$ & 135 & $(68-216)$ & 0.7 \\
\hline$<100$ (no.) & 80 & $(60 \%)$ & 22 & $(63 \%)$ & 0.7 \\
\hline \multicolumn{6}{|l|}{ HIV-1 viral load (log10 copies $/ \mathrm{mL})^{\dagger}$} \\
\hline Median (IQR) & 5.3 & $(4.7-5.5)$ & 5.3 & $(4.8-5.7)$ & 0.5 \\
\hline$<5.0$ (no.) & 50 & $(37 \%)$ & 11 & $(31 \%)$ & 0.5 \\
\hline \multicolumn{6}{|l|}{ Hemoglobin (g/dL) } \\
\hline Median (IQR) & 11.0 & $(9.8-12.1)$ & 11.1 & $(9.8-12.9)$ & 0.6 \\
\hline$<10$ (no.) & 36 & $(27 \%)$ & 10 & $(29 \%)$ & 0.8 \\
\hline \multicolumn{6}{|l|}{ Total lymphocyte count (/mm3) } \\
\hline Median (IQR) & 1578 & $(1080-2100)$ & 1408 & $(1000-1900)$ & 0.4 \\
\hline$<1700$ (no.) & 77 & $(57 \%)$ & 23 & $(66 \%)$ & 0.4 \\
\hline \multicolumn{6}{|l|}{ ALT level $(\times \cup L N)$} \\
\hline Median (IQR) & 0.6 & $(0.4-0.7)$ & 0.8 & $(0.6-1.2)$ & $<0.001$ \\
\hline$\geq 1.25$ (no.) & 8 & $(6 \%)$ & 8 & $(30 \%)$ & 0.002 \\
\hline \multicolumn{6}{|l|}{$\operatorname{ASAT}(\times \cup L N)^{\ddagger}$} \\
\hline Median (IQR) & 0.8 & $(0.6-1.1)$ & 1.3 & $(0.9-1.7)$ & $<0.001$ \\
\hline$\geq 1.25$ (no.) & 21 & $(17 \%)$ & 17 & $(52 \%)$ & $<0.001$ \\
\hline History of antiretroviral treatment (no.) & & & & & 0.6 \\
\hline None & 131 & $(98 \%)$ & 34 & $(97 \%)$ & \\
\hline HAART & 1 & $(1 \%)$ & 1 & $(3 \%)$ & \\
\hline Nevirapine (PMTCT) & 2 & $(2 \%)$ & 0 & - & \\
\hline Baseline antiretroviral treatment (no.) & & & & & 0.3 \\
\hline Zidovudine+lamivudine+nevirapine & 70 & $(52 \%)$ & 15 & $(43 \%)$ & \\
\hline Stavudine+lamivudine+nevirapine & 64 & $(48 \%)$ & 20 & $(57 \%)$ & \\
\hline Cotrimoxazole prophylaxis (no.) & 124 & $(93 \%)$ & 35 & $(100 \%)$ & 0.1 \\
\hline
\end{tabular}

ALT, alanine aminotransferase; AST, aspartate aminotransferase; ULN, upper limit of normal; PMTCT, prevention of mother-to-child transmission; HAART, highly active antiretroviral therapy

* 3 missing values; ${ }^{\dagger} 1$ missing value; ${ }^{*} 9$ missing values

stavudine, lamivudine and nevirapine. Nevirapine was interrupted during follow-up in 16 monoinfected patients (12\%) and 4 coinfected patients (11\%) because of tuberculosis ( $\mathrm{n}=9$ and 2, respectively), adverse effects ( $\mathrm{n}=4$ and 2 , respectively) and antiretroviral drug resistance $(n=3$ and 0 , respectively).

\section{Hepatotoxicity}

A total of 1588 measures of liver enzymes were available. The number of measures per patient was similar in both infection groups (median 10, IQR 9-11, $p=0.2$ ). Two patients only (both were coinfected) had a grade 2 hepatotoxicity at baseline $(90 \mathrm{IU} / \mathrm{L}$ and $97 \mathrm{IU} / \mathrm{L}$, 


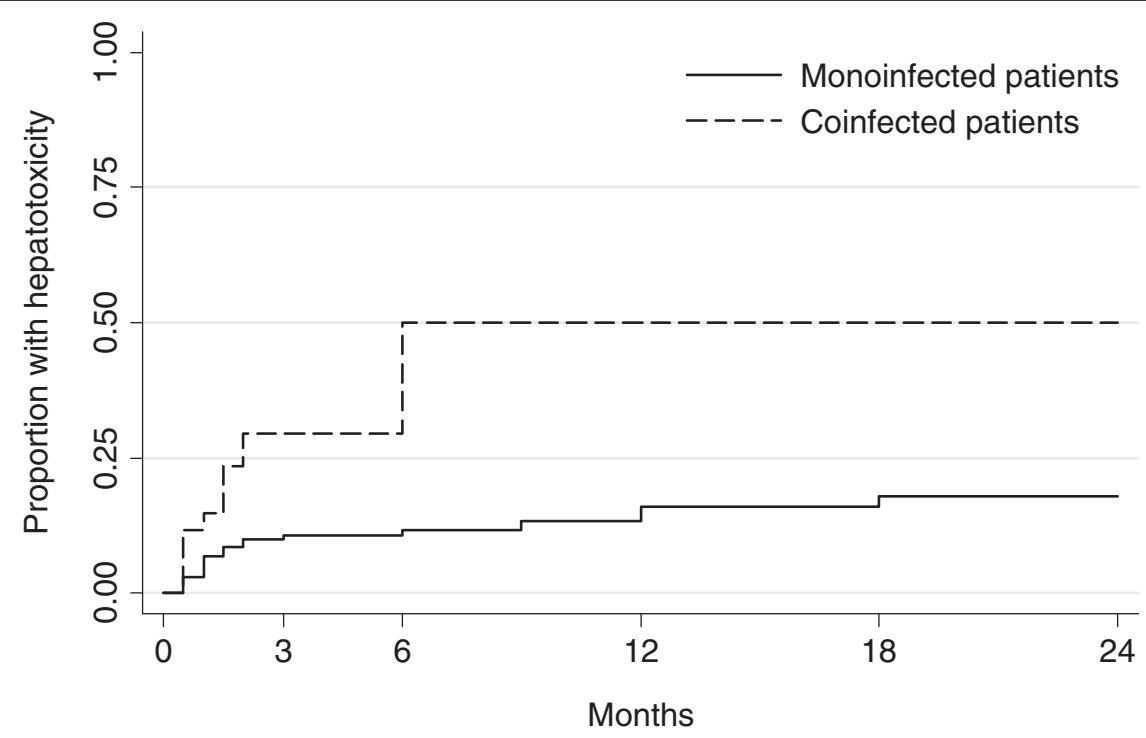

\begin{tabular}{lrrrrrr}
\hline $\begin{array}{l}\text { Number of patients } \\
\text { Monoinfected }\end{array}$ & & & & & \\
$\begin{array}{l}\text { patients } \\
\text { lainfected }\end{array}$ & 131 & 115 & 111 & 98 & 79 & 58 \\
$\begin{array}{l}\text { loints } \\
\text { patients }\end{array}$ & 32 & 23 & 23 & 15 & 12 & 6 \\
\hline
\end{tabular}

Figure 1 Proportion of patients who experienced episodes of grade $\geq 2$ hepatotoxicity by infection group.

respectively); at week 2 , hepatotoxicity dropped to grade 1 in one patient and remained at grade 2 in the other patient. No patient had a baseline grade 3 or 4 hepatotoxicity.

During follow-up, 39 patients experienced at least one episode of grade 2 or higher hepatotoxicity (22 monoinfected patients [16\%] and 17 coinfected patients [49\%]). The corresponding incidence rate was 12.4 per 100 person-years (95\% confidence interval [CI] 8.2-18.9) in monoinfected patients and 54.0 per 100 person-years (CI 33.6-89.5) in coinfected patients. The Kaplan-Meier analysis showed the higher risk in coinfected patients ( $p$
$<0.001$; figure 1). Of note, all episodes of hepatotoxicity in the coinfected patients occurred in the first six months. In monoinfected patients, such episodes occurred throughout the follow-up (although more frequently in the first months). In multivariate Cox analysis, the risk of grade $\geq 2$ hepatotoxicity remained higher in coinfected patients (hazard ratio [HR] 2.94, CI 1.49$5.81, p=0.002$; table 2 ) after adjustement on age (HR 0.90, CI 0.43-1.91, $p=0.8$ ), Karnofsky score (HR 0.41, CI $0.20-0.84, p=0.01$ ) and liver enzymes levels (HR 1.45 , CI $0.74-2.82, p=0.3)$. Of the 17 coinfected patients who experienced a grade $\geq 2$ hepatotoxicity, 4

Table 2 Adjusted risks of outcomes associated with the hepatitis coinfection*

\begin{tabular}{|c|c|c|c|}
\hline Outcome & Ratio or coefficient & $95 \%$ confidence interval & $p$ \\
\hline \multicolumn{4}{|l|}{ Hepatotoxicity } \\
\hline Grade $\geq 2^{+}$ & 2.94 & $1.49-5.81$ & 0.002 \\
\hline Grade $\geq 3^{\dagger}$ & 2.18 & $0.61-7.75$ & 0.2 \\
\hline Highest grade ${ }^{\ddagger}$ & 1.83 & $1.28-2.60$ & 0.001 \\
\hline \multicolumn{4}{|l|}{ CD4 cell count increase ${ }^{\|}$} \\
\hline Primary slope & 0.02 & -0.20 to 0.24 & 0.9 \\
\hline Secondary slope" & -0.04 & -0.38 to 0.31 & 0.8 \\
\hline Quadratic effect" & 0.00 & -0.00 to 0.01 & 0.8 \\
\hline Viral load $<400$ copies $/ \mathrm{mL}^{\dagger}$ & 1.00 & $0.68-1.47$ & 0.9 \\
\hline Death $^{\dagger}$ & 0.52 & $0.14-1.93$ & 0.3 \\
\hline Death or new AIDS-defining event ${ }^{\dagger}$ & 0.37 & $0.11-1.29$ & 0.1 \\
\hline
\end{tabular}

* Coinfected patients versus monoinfected patients. ${ }^{\dagger}$ Cox regression. ${ }^{\ddagger}$ Poisson regression. $"$ Mixed-effect linear regression of the square root-transformed CD4 cell count. " From 6 months to 24 months, combined with the primary slope. 
were positive for HBV (median viral load $1.80 \times 10^{8} \mathrm{IU} /$ $\mathrm{mL}$, IQR $\left.1.04 \times 10^{8}-2.10 \times 10^{8}\right)$ and 13 were positive for HCV (median viral load 970000 IU/mL, IQR 173 800$\left.2.06 \times 10^{6}\right)$.

Only 12 patients $(7 \%)$ experienced a grade 3 or 4 hepatotoxicity (7 monoinfected patients [5\%] and 5 coinfected patients [14\%]). The incidence rates were 3.6 (CI 1.7-7.6) and 9.9 per 100 person-years (CI 4.1-23.7) in monoinfected and coinfected groups, respectively. The risk tended to be higher in coinfected patients but the difference was not significant (HR 2.18, CI 0.61-7.75, $p=0.2$; table 2) after adjustement on age (HR 1.28, CI $0.36-4.53, p=0.8$ ) and liver enzymes levels (HR 1.61, CI $0.47-5.46, p=0.8$ ). All 5 coinfected patients who experienced a grade 3 or 4 hepatotoxicity were $\mathrm{HCV}$ positive; their median viral load was $970000 \mathrm{IU} / \mathrm{mL}$ (IQR 320 $\left.000-1.22 \times 10^{6}\right)$.

The higher risk for hepatotoxicity in coinfected patients was confirmed by the multivariate Poisson regression analysis (incidence risk ratio [IRR] 1.83, CI 1.28-2.60, $p=0.001$; table 2) after adjustement on age (IRR 0.83, CI $0.56-1.24, p=0.4$ ) and Karnofsky score (IRR 0.54, CI 0.39-0.76, $p<0.001$ ).

Three patients developed a rash in the first four weeks (two women with baseline CD4 counts of 31 and 307 cells $/ \mathrm{mm}^{3}$, respectively, and one man with a baseline CD4 count of 18 cells $/ \mathrm{mm}^{3}$ ). Only the male patient was coinfected (HBV viral load $4.88 \times 10^{7} \mathrm{IU} /$ $\mathrm{mL}$ ). Nevirapine was replaced by a protease inhibitor in all three patients. The woman with a high CD4 cell count experienced simultaneously a grade 3 hepatotoxicity. Nevirapine was also replaced by a protease inhibitor in one other (monoinfected) patient with an isolated grade 3 hepatotoxicity. No patient had clinical hepatitis.

\section{Immunological response}

The number of CD4 cell counts per patient was comparable between the monoinfected group (median 5 , IQR 3-5) and the coinfected group (median 4, IQR 4$5 ; p=0.5)$. As shown in figure $2 \mathrm{~A}$, the CD4 cell count increased after treatment initiation from 143 to 325 cells $/ \mathrm{mm}^{3}$ in monoinfected patients and from 136 to 297 cells $/ \mathrm{mm}^{3}$ in coinfected patients. The square root CD4 cell count increase was not significantly different between monoinfected and coinfected patients (either in the first 6 months $[p=0.9]$ and thereafter $[p=0.8]$; table 2) after adjustement on gender (coefficient 1.59, CI 0.41 to $2.77, p=0.008$ ), age (coefficient $-1.07, \mathrm{CI}$ -2.43 to $0.29, p=0.1$ ), HIV-1 viral load (coefficient 1.55 , CI 0.40 to $2.70, p=0.008$ ), hemoglobin level (coefficient 2.43, CI 1.18 to $3.67, p<0.001$ ) and total lymphocyte count (coefficient 2.93 , CI 1.83 to $4.03, p<$ $0.001)$.

\section{Virological response}

The number of HIV-1 RNA measures per patient was similar in both infection groups (median 5, IQR 4-6, $p=$ 0.8 ). The proportion of patients with viral load below 400 copies $/ \mathrm{mL}$ was $91 \%$ and $85 \%$ after 3 months and $91 \%$ and $78 \%$ after 24 months in monoinfected and coinfected patients, respectively (figure $2 \mathrm{~B}$ ). The time for reaching a viral load below 400 copies $/ \mathrm{mL}$ did not differ between the groups (HR 1.00, CI 0.68-1.47, $p=$ 0.9 ; table 2 ). No other variable remained in the model.

\section{Deaths or new AIDS-defining events}

There were 16 deaths (12\%) in monoinfected patients and $3(9 \%)$ in those coinfected. The mortality rates were 7.2 (CI 4.4-11.7) and 4.8 (CI 1.4-15.0) per 100 personyears, respectively. The Kaplan-Meier curves did not differ significantly between the groups ( $p=0.6$, figure $3 \mathrm{~A})$. In multivariate analysis, death was not associated with coinfection (HR 0.52, CI 0.14-1.93, $p=0.3$; table 2) after adjustement on gender (HR 0.29, CI 0.11-0.77, $p=$ 0.01 ), age (HR 1.90, CI 0.68-5.29, $p=0.2$ ), CD4 cell count (HR 0.15, CI 0.04-0.55, $p=0.004$ ) and hemoglobin level (HR 0.28, CI 0.11-0.74, $p=0.01$ ). In the monoinfected group, the deaths were related to advanced HIV disease $(n=5)$, poor general health $(n=5)$, multifocal tuberculosis, pulmonary infection, wasting, malaria, pancreatitis and hepatic carcinoma $(\mathrm{n}=1$ each). In the coinfected group, death was related to advanced HIV disease, poor general health and persistent fever of unknown origin ( $\mathrm{n}=1$ each); the first two patients had taken traditional medicines.

Deaths or new AIDS-defining events occurred in 25 monoinfected patients (19\%) and 5 coinfected patients (14\%). The respective incidence rates were 10.6 (CI 7.016.1) and 6.7 per 100 person-years (CI 2.5-17.8). The Kaplan-Meier curves showed no significant difference between the groups ( $p=0.5$, figure $3 \mathrm{~B})$. In multivariate analysis, the occurrence of deaths or new AIDS-defining events was not associated with coinfection (HR 0.37, CI $0.11-1.29, p=0.1$; table 2) after adjustement on age (HR 1.33, CI $0.53-3.32, p=0.5$ ) and body mass index (HR 4.40, CI 1.98-9.78, $p<0.001)$.

\section{Discussion}

This study in Cameroon showed a higher hepatotoxicity in HBV or HCV-coinfected patients receiving a nevirapine-based antiretroviral therapy than in their HIVmonoinfected homologues. However, this adverse event did not impact negatively on the effectiveness of treatment.

Altogether, our analyses showed that the risk of hepatotoxicity was 2 -fold higher in hepatitis $B$ or $C$ coinfected patients. This finding is consistent with previous reports $[11,17,27,28]$, especially with a study in patients 
A

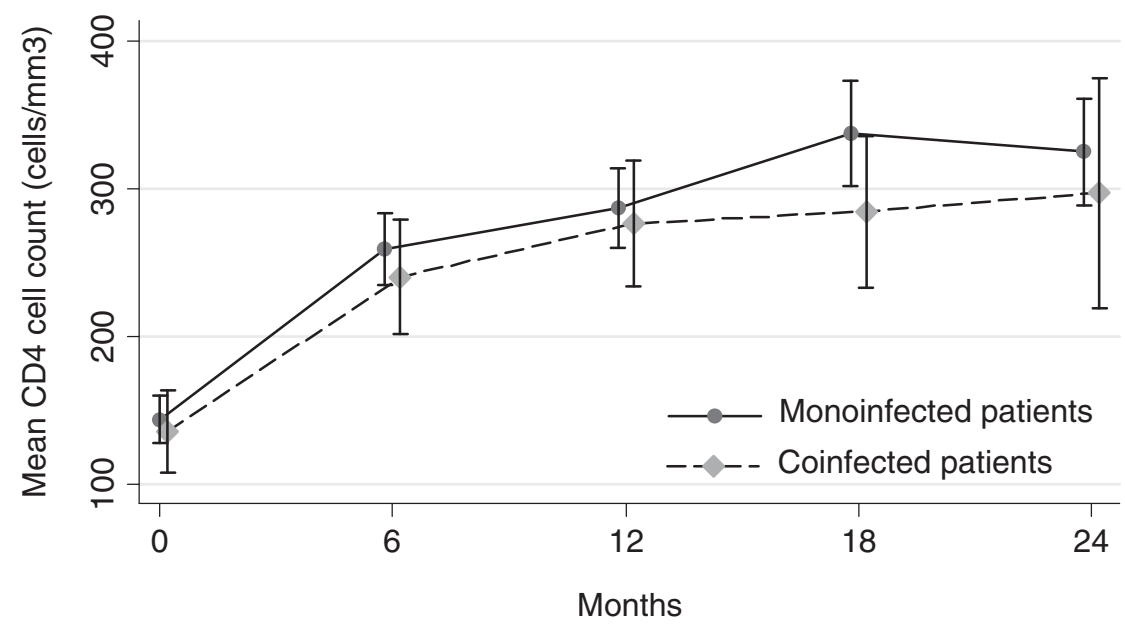

\begin{tabular}{lrrrrr}
\hline Number of patients & & & & \\
\hline $\begin{array}{l}\text { Monoinfected } \\
\text { patients }\end{array}$ & 134 & 123 & 113 & 93 & 72 \\
$\begin{array}{l}\text { Coinfected } \\
\text { patients }\end{array}$ & 35 & 32 & 32 & 25 & 21 \\
\hline
\end{tabular}

B

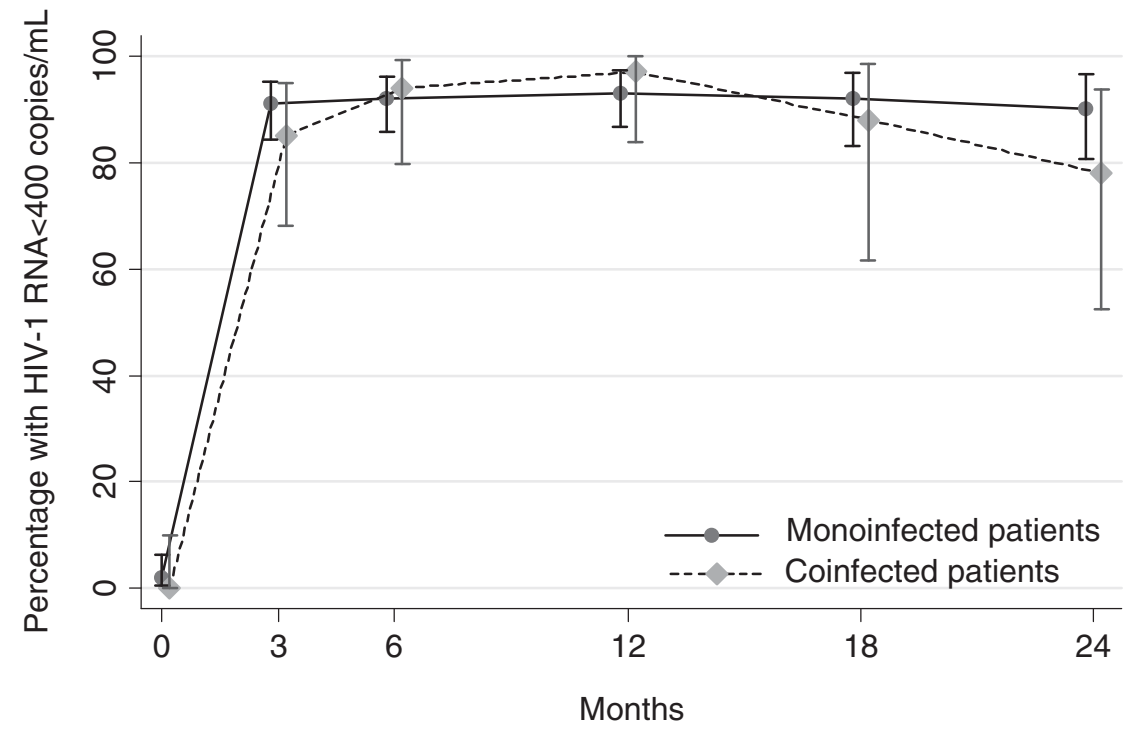

\begin{tabular}{lrrrrrr}
\hline \multicolumn{2}{l}{ Number of patients } & & & & \\
\hline $\begin{array}{l}\text { Monoinfected } \\
\text { patients }\end{array}$ & 133 & 128 & 125 & 104 & 73 & 64 \\
$\begin{array}{l}\text { Coinfected } \\
\text { patients }\end{array}$ & 35 & 33 & 33 & 32 & 16 & 18 \\
\hline
\end{tabular}

Figure 2 Immunological and virological responses to antiretroviral therapy by infection group: mean CD4 cell count (A), and percentage of patients with plasma HIV-1 viral load below $\mathbf{4 0 0}$ copies $/ \mathbf{m L}$ (B). Bars indicate $95 \%$ confidence intervals. 
A

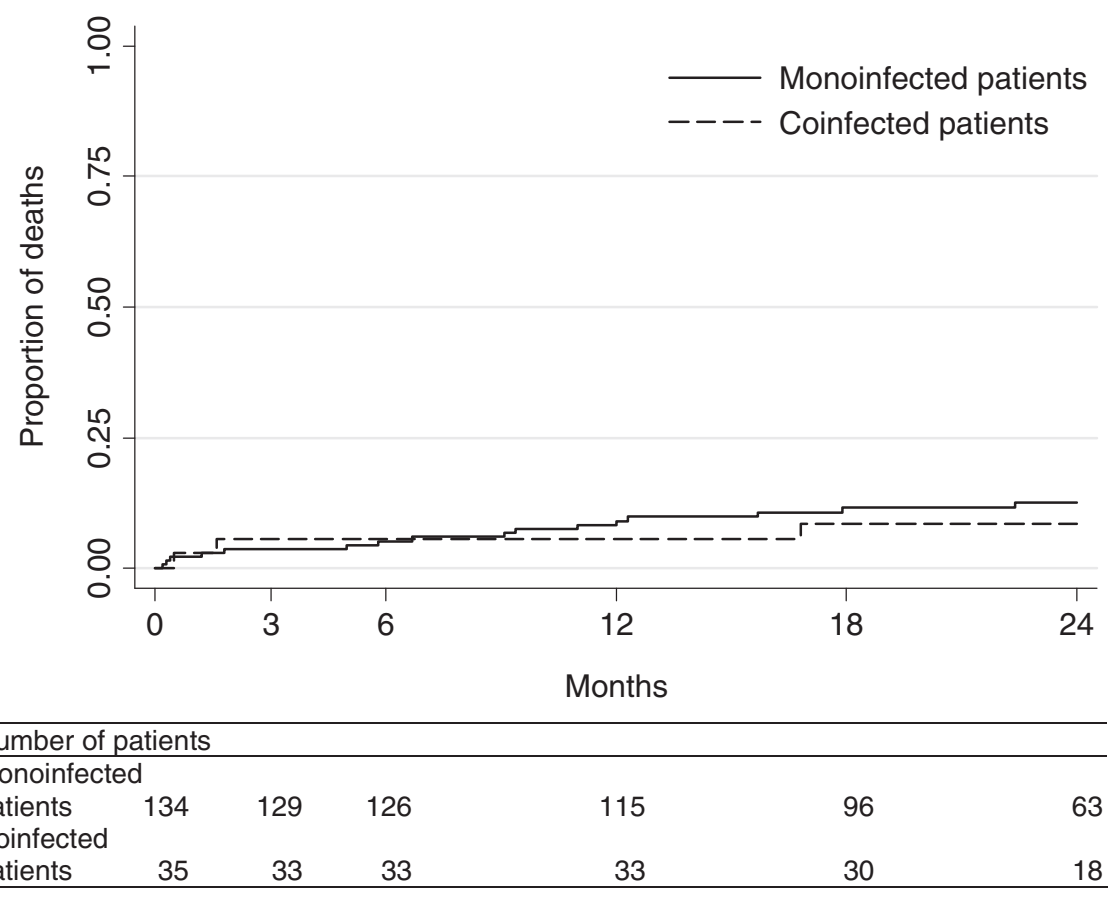

B

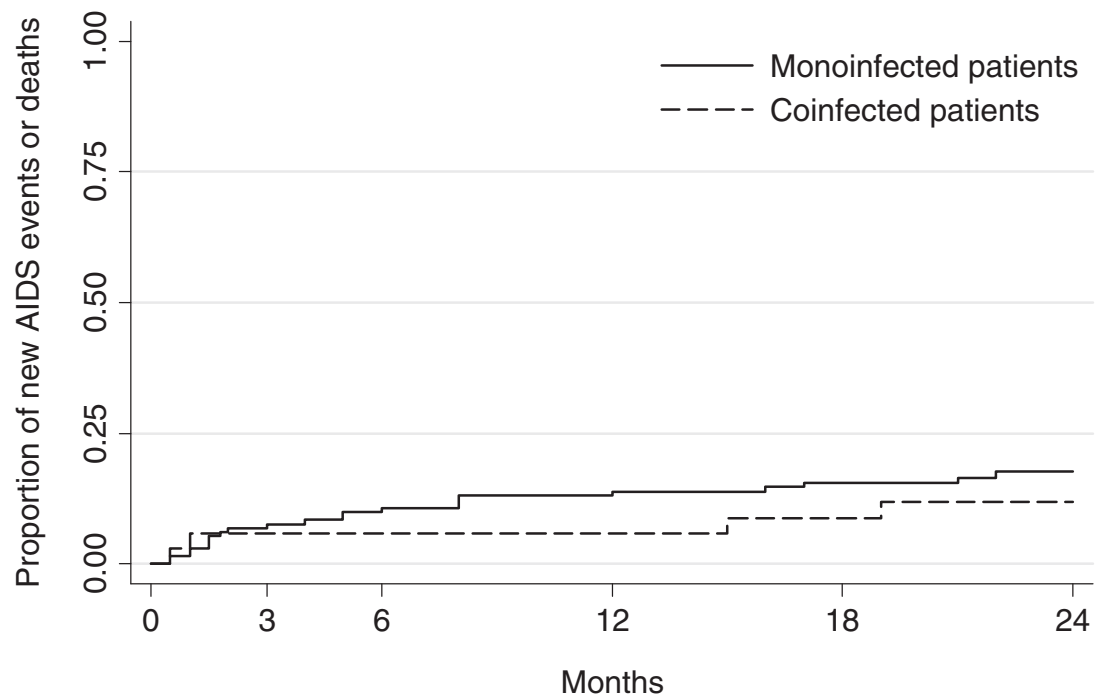

\begin{tabular}{|c|c|c|c|c|c|c|}
\hline \\
\hline \multicolumn{7}{|c|}{ Monoinfected } \\
\hline & 131 & 122 & 117 & 106 & 90 & \\
\hline patients & 34 & 32 & 32 & 32 & 29 & 18 \\
\hline
\end{tabular}

Figure 3 Clinical progression by infection group: progression to death (A), and progression to death or new AIDS-defining event (B). 
receiving a nevirapine-based treatment in United States [29]. Of note, HCV-coinfected patients accounted for $76 \%$ of overall coinfected patients with liver enzymes elevations $>2.5$ times the ULN (ALT and/or AST levels) during treatment and $100 \%$ of those with liver enzymes elevations $>5$ times the ULN (as compared with $60 \%$ of the study's coinfected group). It should however be noted that HCV infection was not treated while HBV infection was treated with lamivudine monotherapy. Although anti-HBV lamivudine monotherapy has been shown to lead to frequent emergence of drug resistance [30] and, consequently, to possible acute hepatitis, fulminant hepatic failure, and death [3], lamivudine was likely to be effective against HBV in the first months of treatment when most episodes of hepatotoxicity occurred. Importantly, up to half the coinfected patients experienced liver enzymes elevations $>2.5$ times the ULN.

Overall, the hepatic tolerability of the nevirapine-based antiretroviral therapy was as expected. Seven percents of patients experienced liver enzymes elevations $>5$ times the ULN. In a comprehensive analysis of 17 randomized clinical trials of nevirapine, the rate was $10 \%$ after one year of treatment [31]. A higher rate of $17 \%$ has been found in South African patients who had a mean baseline CD4 count of 398 cells $/ \mathrm{mm}^{3}$ [32]. Our lower rate should be explained by the profound immunodeficiency of our patients at the time of treatment initiation (median CD4 count of 135 cells $/ \mathrm{mm}^{3}$ ). Indeed, transaminases elevations $>5$ times the ULN in patients receiving nevirapine has been associated with sex-dependant CD4 cell count [5]. Thus, nevirapine should be avoided in women with a CD4 count above 250 cells $/ \mathrm{mm}^{3}$ and in men with a CD4 count above 400 cells $/ \mathrm{mm}^{3}$. In our study, only $13 \%$ of women and no man had a CD4 cell count above these respective cuttoffs. Most transaminases elevations in our patients were asymptomatic. Only $2 \%$ of patients had a rash following treatment initiation. In their analysis, Dieterich et al found a rash in $2.2 \%$ of patients [31]. On the other hand, the incidence rates of liver enzymes elevations $>5$ times the ULN in our monoinfected and coinfected patients were comparable to those reported in South African patients receiving an efavirenz-based antiretroviral therapy [7].

The immunological response to the nevirapine-based antiretroviral therapy was comparable between coinfected and monoinfected patients, in accordance with several studies irrespective of the treatment prescribed $[7,11,13,14,18,20]$. In contrast, other studies found delayed CD4 cell count recovery in coinfected patients especially in those coinfected with HCV [8-10,21]. However, this lower immunological response was not sustained beyond the first few months in the Thai and Swiss studies [10,33].
The virological response also was comparable between patients coinfected with an hepatitis virus and patients infected with HIV only. Increased risk for virological failure has been reported in HBV-coinfected patients in Taiwan [11]. However, most other studies like ours did not find any difference $[7,9,10,17,21]$.

The clinical progression did not differ significantly between coinfected and monoinfected patients but treatment was initiated late (median CD4 count of 135 cells/ $\mathrm{mm}^{3}$ ). Surprisingly, deaths or new AIDS-defining events were less common in coinfected patients. A possible explanation could be a close medical supervision of coinfected patients owing to frequent liver enzymes elevations. Higher rates of deaths (from any cause, liverrelated causes and/or AIDS-related causes) and/or new AIDS-defining events in patients coinfected with HBV or $\mathrm{HCV}$ has been reported by some $[8,11-16,18,20]$ but not all studies $[7,9,10,17]$. In our study, only one death was from a liver-related cause and this was recorded in a monoinfected patient. Intake of traditional medicines which have a potential for hepatic toxicity was however reported in two of the three coinfected patients who died.

The main limitation to our study was the relatively small sample size. However, a significant higher risk of hepatotoxicity in coinfected patients was demonstrated. Also, the absence of viral hepatitis impact on immunological and virological responses to antiretroviral therapy was strongly suggested by the regression coefficients and hazard ratio, respectively. Finally, the risk of clinical progression tended to decrease in coinfected patients which is likely to be related to an unmeasured confounding factor. The exclusion of patients presenting with serum liver enzyme levels higher than three or five times the ULN values (depending on the initial study) could have led to a selection bias (exclusion of patients with an advanced hepatitis clinical stage) but this is concordant with the recommendations for nevirapine use. Classification biases for hepatitis status could also not be ruled out because seronegative blood samples were not tested for HBV DNA or HCV RNA. Higher rates of negative HBsAg or anti-HCV results in viraemic samples have been observed in immunocompromised HIV-infected patients $[3,4]$. In addition, unrepeated testing of HBV and $\mathrm{HCV}$ during follow-up did not allow to identify new or reactivated hepatitis infections. New infections, if any, were however likely to be rare owing to the study's duration and, for HBV, the usual childhood infections in Africa through close contacts within households and, to a lesser extent, vertical transmission (unclear modes of transmission for $\mathrm{HCV}$ ) [1]. On the other hand, no symptomatic reactivated hepatitis infections were recorded. In contrast, classification of patients on the basis of HBV DNA and HCV RNA is clearly a strength 
of our study while most other studies only used serological assays.

\section{Conclusion}

This study suggests that the nevirapine-based antiretroviral therapy could be used safely as first-line treatment in patients with low CD4 cell count in Africa despite frequent coinfections with $\mathrm{HBV}$ or $\mathrm{HCV}$ and infrequent testing of these infections. Although testing for HBV and $\mathrm{HCV}$ should be systematically performed before initiating antiretroviral therapy, transaminases elevations at baseline or during treatment should be a decisive argument for testing when hepatitis status is unknown.

\section{Acknowledgements}

We thank all the patients and staff of the Military Hospital and Central Hospital who participated in the study, and the National AIDS Programme, Yaoundé, Cameroon. The study was supported by the French National Agency for Research on AIDS and viral hepatitis (ANRS 1274), Institut de Recherche pour le Développement (France) and Médecins Sans Frontières (Switzerland). Jules Brice Tchatchueng Mbougua was the recipient of a doctoral fellowship from the Institut de Recherche pour le Développement.

\section{Author details}

${ }^{1}$ Institut de Recherche pour le Développement, University Montpellier 1, UMR 145, Montpellier, France. ${ }^{2}$ National advanced school of engineering, University Yaoundé 1, Yaoundé, Cameroon. ${ }^{3}$ Central Hospital, Yaoundé, Cameroon. ${ }^{4}$ University Hospital, Department of Infectious and Tropical Diseases, Montpellier, France. ${ }^{5}$ Médecins Sans Frontières, Geneva, Switzerland. ${ }^{6}$ University Hospital, Laboratory of viral hepatitis, Montpellier, France. ${ }^{7}$ Military hospital, Yaoundé, Cameroon. ${ }^{8}$ Department of Biostatistics, University Montpellier 1, Montpellier, France. ${ }^{9}$ University Hospital, Department of Biostatistics, Nîmes, France.

\section{Authors' contributions}

JBTM analysed the data and, with $\mathrm{CL}$, wrote the first draft of the report. $\mathrm{CL}$ also designed the study and contributed to data collection, analysis and interpretation of data. $\mathrm{HG}$ and $\mathrm{NM}$ contributed to data analysis. CK, $A B, L C$, $A C, S K S, J D, E M N$ and ED contributed to data collection, interpretation of data and drafting of manuscript. All authors read and approved the final draft of the manuscript.

\section{Competing interests}

The authors declare that they have no competing interests.

Received: 1 December 2009

Accepted: 1 March 2010 Published: 1 March 2010

\section{References}

1. Modi AA, Feld JJ: Viral hepatitis and HIV in Africa. AIDS Rev 2007, 9(1):25-39.

2. Soriano V, Puoti M, Garcia-Gasco P, Rockstroh JK, Benhamou Y, Barreiro P, McGovern B: Antiretroviral drugs and liver injury. Aids 2008, 22(1):1-13.

3. Hoffmann CJ, Thio CL: Clinical implications of HIV and hepatitis B coinfection in Asia and Africa. Lancet Infect Dis 2007, 7(6):402-9.

4. Rockstroh JK, Spengler U: HIV and hepatitis C virus co-infection. Lancet Infect Dis 2004, 4(7):437-44.

5. Stern JO, Robinson PA, Love J, Lanes S, Imperiale MS, Mayers DL: A comprehensive hepatic safety analysis of nevirapine in different populations of HIV infected patients. J Acquir Immune Defic Syndr 2003, 34(Suppl 1):S21-33.

6. World Health Organization: Antiretroviral therapy for HIV infection in adults and adolescents in resource-limited settings: towards universal access. Recommandations for a public health approach. Geneva: World Health Organization 2006, 140.
7. Hoffmann CJ, Charalambous S, Martin DJ, Innes C, Churchyard GJ, Chaisson RE, Grant $A D$, Fielding $K L$, Thio $C L$ : Hepatitis $B$ virus infection and response to antiretroviral therapy (ART) in a South African ART program. Clin Infect Dis 2008, 47(11):1479-85.

8. Greub $G$, Ledergerber B, Battegay M, Grob P, Perrin L, Furrer $H$, Burgisser $P$ Erb P, Boggian K, Piffaretti JC, Hirschel B, Janin P, Francioli P, Flepp M, Telenti $A$ : Clinical progression, survival, and immune recovery during antiretroviral therapy in patients with HIV-1 and hepatitis $C$ virus coinfection: the Swiss HIV Cohort Study. Lancet 2000, 356(9244):1800-5.

9. Lincoln D, Petoumenos K, Dore GJ: HIV/HBV and HIV/HCV coinfection, and outcomes following highly active antiretroviral therapy. HIV Med 2003, 4(3):241-9.

10. Law WP, Duncombe CJ, Mahanontharit A, Boyd MA, Ruxrungtham K, Lange JM, Phanuphak P, Cooper DA, Dore GJ: Impact of viral hepatitis coinfection on response to antiretroviral therapy and HIV disease progression in the HIV-NAT cohort. AIDS 2004, 18(8):1169-77.

11. Sheng WH, Chen MY, Hsieh SM, Hsiao CF, Wang JT, Hung CC, Chang SC Impact of chronic hepatitis B virus (HBV) infection on outcomes of patients infected with HIV in an area where HBV infection is hyperendemic. Clin Infect Dis 2004, 38(10):1471-7.

12. Bonacini M, Louie S, Bzowej N, Wohl AR: Survival in patients with HIV infection and viral hepatitis B or C: a cohort study. AIDS 2004, 18(15):2039-45.

13. Konopnicki D, Mocroft A, de Wit S, Antunes F, Ledergerber B, Katlama C, Zilmer K, Vella S, Kirk O, Lundgren JD: Hepatitis B and HIV: prevalence, AIDS progression, response to highly active antiretroviral therapy and increased mortality in the EuroSIDA cohort. AIDS 2005, 19(6):593-601.

14. Rockstroh JK, Mocroft A, Soriano V, Tural C, Losso MH, Horban A, Kirk O, Phillips A, Ledergerber B, Lundgren J: Influence of hepatitis $C$ virus infection on HIV-1 disease progression and response to highly active antiretroviral therapy. J Infect Dis 2005, 192(6):992-1002.

15. Backus LI, Phillips BR, Boothroyd DB, Mole LA, Burgess J, Rigsby MO, Chang SW: Effects of hepatitis $C$ virus coinfection on survival in veterans with HIV treated with highly active antiretroviral therapy. J Acquir Immune Defic Syndr 2005, 39(5):613-9.

16. Weis $N$, Lindhardt $B O$, Kronborg $G$, Hansen $A B$, Laursen $A L$, Christensen $P B$, Nielsen $\mathrm{H}$, Moller A, Sorensen HT, Obel N: Impact of hepatitis $C$ virus coinfection on response to highly active antiretroviral therapy and outcome in HIV-infected individuals: a nationwide cohort study. Clin Infect Dis 2006, 42(10):1481-7.

17. Zhou J, Dore GJ, Zhang F, Lim PL, Chen YM: Hepatitis B and C virus coinfection in The TREAT Asia HIV Observational Database. $J$ Gastroenterol Hepatol 2007, 22(9):1510-8.

18. Omland LH, Weis N, Skinhoj P, Laursen A, Christensen PB, Nielsen HI, Moller A, Engsig F, Sorensen HT, Obel N: Impact of hepatitis B virus coinfection on response to highly active antiretroviral treatment and outcome in HIV-infected individuals: a nationwide cohort study. HIV Med 2008, 9(5):300-6

19. Carmo RA, Guimaraes MD, Moura AS, Neiva AM, Versiani JB, Lima LV, Freitas LP, Rocha MO: The influence of HCV coinfection on clinical, immunological and virological responses to HAART in HIV-patients. Braz $J$ Infect Dis 2008, 12(3):173-9.

20. Hoffmann CJ, Seaberg EC, Young S, Witt MD, D'Acunto K, Phair J, Thio CL: Hepatitis $B$ and long-term HIV outcomes in coinfected HAART recipients. AIDS 2009, 23(14):1881-9.

21. De Luca A, Bugarini R, Lepri AC, Puoti M, Girardi E, Antinori A, Poggio A, Pagano G, Tositti G, Cadeo G, Macor A, Toti M, D'Arminio Monforte A: Coinfection with hepatitis viruses and outcome of initial antiretroviral regimens in previously naive HIV-infected subjects. Arch Intern Med 2002, 162(18):2125-32.

22. Laurent C, Bourgeois A, Mpoudi-Ngole E, Kouanfack C, Ciaffi L, Nkoue N, Mougnutou R, Calmy A, Koulla-Shiro S, Ducos J, Delaporte E: High rates of active hepatitis B and C co-infections in HIV-1 infected Cameroonian adults initiating antiretroviral therapy. HIV Med 2010, 11(1):85-9.

23. Laurent C, Kouanfack C, Koulla-Shiro S, Nkoué N, Bourgeois A, Calmy A, Lactuock B, Nzeusseu V, Mougnutou R, Peytavin G, Liegeois F, Nerrienet E, Tardy M, Peeters M, Andrieux-Meyer I, Zekeng L, Kazatchkine M, MpoudiNgole E, Delaporte E: Effectiveness and safety of a generic fixed-dose combination of nevirapine, stavudine, and lamivudine in HIV-1-infected adults in Cameroon: open-label multicentre trial. Lancet 2004 364(9428):29-34 
24. Bourgeois A, Laurent C, Mougnutou R, Nkoué N, Lactuock B, Ciaffi L, Liégeois F, Andrieux-Meyer I, Zekeng L, Calmy A, Mpoudi-Ngolé E, Delaporte E: Field assessment of generic antiretroviral drugs: a prospective cohort study in Cameroon. Antivir Ther 2005, 10(2):335-41.

25. Laurent C, Kouanfack C, Koulla-Shiro S, Njoume M, Mawanba Nkene Y, Ciaffi L, Brulet C, Peytavin G, Vergne L, Calmy A, Mpoudi-Ngolé E, Delaporte $\mathrm{E}$ : Long-term safety, effectiveness and quality of a generic fixed-dose combinaison of nevirapine, stavudine and lamivudine. AIDS 2007, 21(6):768-71.

26. De Beaudrap P, Etard JF, Diouf A, Ndiaye I, Gueye NF, Gueye PM, Sow PS, Mboup S, Ndoye I, Ecochard R, Delaporte E: Modeling CD4+ cell count increase over a six-year period in HIV-1-infected patients on highly active antiretroviral therapy in Senegal. Am J Trop Med Hyg 2009, 80(6):1047-53.

27. Hoffmann CJ, Charalambous S, Thio CL, Martin DJ, Pemba L, Fielding KL, Churchyard GJ, Chaisson RE, Grant AD: Hepatotoxicity in an African antiretroviral therapy cohort: the effect of tuberculosis and hepatitis $B$. Aids 2007, 21(10):1301-8.

28. den Brinker M, Wit FW, Wertheim-van Dillen PM, Jurriaans S, Weel J, van Leeuwen R, Pakker NG, Reiss P, Danner SA, Weverling GJ, Lange JM: Hepatitis $B$ and $C$ virus co-infection and the risk for hepatotoxicity of highly active antiretroviral therapy in HIV-1 infection. AIDS 2000, 14(18):2895-902.

29. Sulkowski MS, Thomas DL, Mehta SH, Chaisson RE, Moore RD: Hepatotoxicity associated with nevirapine or efavirenz-containing antiretroviral therapy: role of hepatitis $C$ and $B$ infections. Hepatology 2002, 35(1):182-9.

30. Matthews GV, Bartholomeusz A, Locarnini S, Ayres A, Sasaduesz J Seaberg E, Cooper DA, Lewin S, Dore GJ, Thio CL: Characteristics of drug resistant $\mathrm{HBV}$ in an international collaborative study of HIV-HBV-infected individuals on extended lamivudine therapy. Aids 2006, 20(6):863-70.

31. Dieterich DT, Robinson PA, Love J, Stern JO: Drug-induced liver injury associated with the use of nonnucleoside reverse-transcriptase inhibitors. Clin Infect Dis 2004, 38(Suppl 2):S80-9.

32. Sanne I, Mommeja-Marin H, Hinkle J, Bartlett JA, Lederman MM, Maartens G, Wakeford C, Shaw A, Quinn J, Gish RG, Rousseau F: Severe hepatotoxicity associated with nevirapine use in HIV-infected subjects. J Infect Dis 2005, 191(6):825-9.

33. Kaufmann GR, Perrin L, Pantaleo G, Opravil M, Furrer $H$, Telenti A, Hirschel B, Ledergerber B, Vernazza P, Bernasconi E, Rickenbach M, Egger $M$,

Battegay M: CD4 T-lymphocyte recovery in individuals with advanced HIV-1 infection receiving potent antiretroviral therapy for 4 years: the Swiss HIV Cohort Study. Arch Intern Med 2003, 163(18):2187-95.

Pre-publication history

The pre-publication history for this paper can be accessed here:http://www biomedcentral.com/1471-2458/10/105/prepub

doi:10.1186/1471-2458-10-105

Cite this article as: Mbougua et al:: Hepatotoxicity and effectiveness of a Nevirapine-based antiretroviral therapy in HIV-infected patients with or without viral hepatitis B or C infection in Cameroon. BMC Public Health 2010 10:105.

\section{Submit your next manuscript to BioMed Central and take full advantage of:}

- Convenient online submission

- Thorough peer review

- No space constraints or color figure charges

- Immediate publication on acceptance

- Inclusion in PubMed, CAS, Scopus and Google Scholar

- Research which is freely available for redistribution 